\section{EVALUATION ON THE REDUCED GRAPHENE OXIDE THERMAL INTERFACE MATERIAL AND HEAT SPREADER FOR THERMAL MANAGEMENT IN HIGH-TEMPERATURE POWER DEVICE}

Mohd Faizol Abdullah*, Siti Aishah Mohamad Badaruddin, Mohd Rofei Mat Hussin, Mohd Ismahadi Syono

Advanced Devices Lab, MIMOS Berhad, Technology Park Malaysia, 57000 Kuala Lumpur, Malaysia
Article history

Received

23 July 2020

Received in revised form

26 November 2020

Accepted

3 December 2020

Published online

22 April 2021

*Corresponding author faizol.abdullah@mimos.my

\section{Graphical abstract}
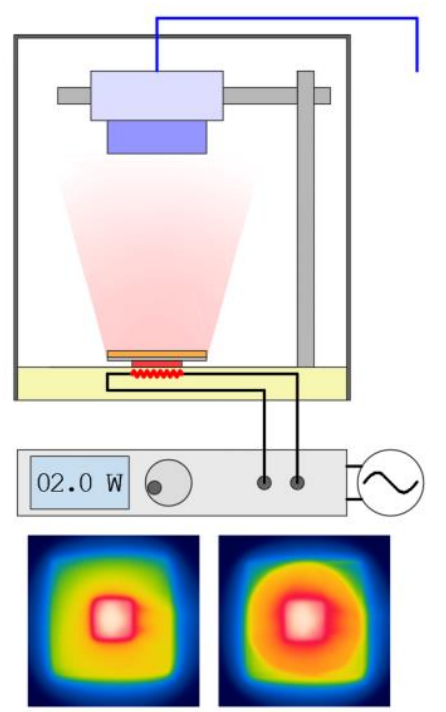

\begin{abstract}
Thermally conductive reduced graphene oxide ( $\mathrm{rGO}$ ) is desirable for removing generated heat during the operation of a power device. Excessive heat accumulation results in device failure. In this article, the performance of rGO as a thermal interface material (TIM) and heat spreader on Si substrate was evaluated using a custom build thermal test setup. By a simple drop-casting of graphene oxide (GO) on Si followed by $700{ }^{\circ} \mathrm{C}$ thermal reduction, a hybrid film of GO (electrical insulator) and rGO (thermal conductor) was obtained. This was verified by Raman spectra and surface morphological image. Approximately $300 \mathrm{~nm}$-thick rGO film prepared from 4-times drop-casting of GO exhibited the highest performance as a TIM and heat spreader. The heating rate of $\mathrm{Si}$ increased from $14.85^{\circ} \mathrm{C} / \mathrm{W}$ to $18.37^{\circ} \mathrm{C} / \mathrm{W}$ due to the improved heat transfer from the heater into the Si substrate. The experimental results endorsed the effectiveness of rGO as a thermal solution and verified the capability of the thermal test setup as a thermal simulation of a high-power device.
\end{abstract}

Keywords: Reduced graphene oxide, thermal interface material, heat spreader; thermal management, power device

\begin{abstract}
Abstrak
Pengalir haba grafin oksida terturun (rGO) adalah diperlukan untuk membuang haba yang dijana semasa operasi peranti kuasa. Haba terkumpul yang berlebihan menyebabkan kegagalan peranti. Dalam artikel ini, prestasi rGO sebagai bahan terma antaramuka (TIM) dan penyebar haba di atas substrat Si dinilai menggunakan persediaan ujian termal binaan khas. Dengan cara tuangan jatuhan grafin oksida (GO) yang ringkas diikuti oleh penurunan termal $700{ }^{\circ} \mathrm{C}$, filem hibrid GO (penebat elektrik) dan rGO (pengalir haba) telah diperoleh. lanya disahkan oleh spektrum Raman dan imej morfologi permukaannya. Filem rGO yang tebal beranggaran $300 \mathrm{~nm}$ disediakan dari 4-kali tuangan jatuhan GO menunjukkan prestasi tertinggi sebagai TIM dan penyebar haba. Kadar pemanasan Si telah ditingkatkan dari 14.85 - $\mathrm{C} / \mathrm{W}$ kepada $18.37^{\circ} \mathrm{C} / \mathrm{W}$ disebabkan oleh penambahbaikan pemindahan haba dari pemanas ke dalam substrat Si. Hasil-hasil eksperimen telah menyokong keberkesanan rGO sebagai penyelesaian termal dan mengesahkan kebolehan persediaan ujian termal binaan khas ini sebagai simulasi termal bagi peranti kuasa tinggi.
\end{abstract}

Kata kunci: Grafin oksida terturun, bahan terma antaramuka, penyebar haba, pengurusan termal, peranti kuasa

(C) 2021 Penerbit UTM Press. All rights reserved 


\subsection{INTRODUCTION}

Thermal management in high-power semiconductor devices is essential to mitigate performance degradation issues due to excessive heat accumulation. One of the approaches to address this issue is through the incorporation of high thermal conductivity materials, e.g. 2-dimensional (2D) graphene and reduced graphene oxide (rGO) as a heat spreader at device-level [1, 2], and thermal interface material (TIM) at packaging-level application [3]. For this purpose, exceptionally high thermal conductivity graphene up to $5150 \mathrm{~W} / \mathrm{mK}$ [4] and $\mathrm{rGO}$ up to $2600 \mathrm{~W} / \mathrm{mK}$ [5] are both appealing. However, both of them are not truly versatile in terms of integration to the desired hotspot area since they are electrically conductive and may short circuit the device itself. It requires additional countermeasures such as lithography to pattern the graphene [6], or by embedding graphene under the insulator [7]. Such strategies somehow will affect the effectiveness of graphene heat spreader in the actual operation.

Graphene oxide (GO) as the precursor for rGO may provide an alternative solution to the problem. $G O$ is typically synthesized in aqueous dispersion form [8]. Amphiphilic GO sheet contains hydrophilic edges contributed by the oxygen functional groups, while its un-oxidized basal plane remains hydrophobic [9]. Before de-oxygenation (reduction), GO dispersion acts as a hydrophilic droplet and easy to form a continuous film even on the hydrophobic and textured surface $[10,11]$. GO has an inferior electrical and thermal conductivity as the consequence of oxidation during aqueous phase exfoliation [12]. It is imaginable to produce a material that possesses the characteristic of thermally conductive yet electrically insulating by incomplete reduction of GO into rGO. To synthesize such a hybrid layer, a considerably thick layer of GO should be deposited and then deoxygenate the outer layer into electrical and thermally conductive rGO.

In this work, we built a custom thermal test measurement setup to evaluate the performance of mildly de-oxygenated $\mathrm{rGO}$ as a TIM and heat spreader. We acknowledge the available test method to obtain the value of thermal conductivity for 2D materials currently rather be sophisticated [1214]. Even though it is done, the actual in-device thermal performance of those materials may not relatable to the thermal conductivity measurement result as they are sensitive to the external factor e.g. residual fabrication, the effect of substrate, and the difference in test ambient. Therefore, it is necessary to come out with another method to study thermal performance that may closely represent the actual operation of semiconductor power devices. We discussed our verdicts on rGO as a TIM and heat spreader on bulk Si and as well relevant to the other semiconductor substrates.

\subsection{METHODOLOGY}

Si wafer was cut into pieces of $3 \times 3 \mathrm{~cm}^{2}$ to be used as substrates. Samples were subjected to the ultrasonic-assisted organic cleaning in acetone for 5 $\mathrm{min}$, rinsed in isopropanol, then blow-dried. Samples were dipped into $10 \%$ hydrofluoric acid for $30 \mathrm{sec}$ to remove the native oxide, then followed by rinsing in de-ionized (DI) water and blow-dried. GO was synthesized by the improved Hummer method as described in ref. [15]. Single-layer GO sheets after the aqueous-phase exfoliation process were dispersed in DI water at a concentration of approximately 2 $\mathrm{mg} / \mathrm{ml}$. GO film was deposited onto a polished $\mathrm{Si}$ substrate by drop-cast method, in a similar manner to our previous work in ref. [16]. The droplet was left with slow-drying on $60{ }^{\circ} \mathrm{C}$ hotplate to evaporate water that disperses the GO sheets. Slow-drying is necessary to avoid rigorous movement of dispersed $G O$ sheets during the removal of water. By this method, the diameter of $\mathrm{GO}$ film can be controlled by the volume of $\mathrm{GO}$ droplets assisted by surface tension between hydrophobic Si and hydrophilic GO. The diameter of the $\mathrm{GO}$ film for every drop-casting was $3 \mathrm{~cm}$ similar to the dimension of the Si substrate.

Drop-cast of the GO droplet was repeated from 1 - 4 to vary the thickness of GO film. Based on the volume of drop-casted GO, each droplet took around $30 \mathrm{~min}$ to fully dried on $60{ }^{\circ} \mathrm{C}$ hotplate. Repetition of drop-casting was done after complete slow-drying of each layer. The samples 1 - 4 were then dried on $100{ }^{\circ} \mathrm{C}$ hotplate for $10 \mathrm{~min}$ for complete removal of trapped water within GO film. The GO was converted into reduced GO (rGO) by high-temperature heat treatment. The samples were annealed in 400 mTorr $\mathrm{H}_{2}$ chamber (Oxford Plasmalab System 100) at $700{ }^{\circ} \mathrm{C}$ for $30 \mathrm{~min}$. The final sample was labeled as Si with rGO (1) - (4) film with respect to the amount of $\mathrm{GO}$ drop-cast.

The crystal condition of rGO was investigated using 432 nm Raman spectroscopy (NTEGRA Spectra MT-MDT) at room temperature. The thickness of rGO was measured by spectroscopic ellipsometry (Semilab SE-2000) at several spots on the center area of sample. Morphology of $\mathrm{rGO}$ coating on $\mathrm{Si}$ was studied using field emission scanning electron microscopy (FESEM) system (JEOL JSM-7500 F) at 500x magnification. The thermal performance of the rGO heat spreader on Si was investigated using a custom build system as schematically shown in Figure 1. The system consists of a $1 \times 1 \mathrm{~cm}^{2} \mathrm{Pt}$ heater (capped) and a pre-calibrated infrared (IR) camera (FLIR ETS320). The sample was placed onto the heater plate in such manner of rGO film acts as a TIM between the heater and Si. The measurement was conducted in enclosed ambient at room temperature of $23^{\circ} \mathrm{C}$ and relative humidity of $50 \%$. 


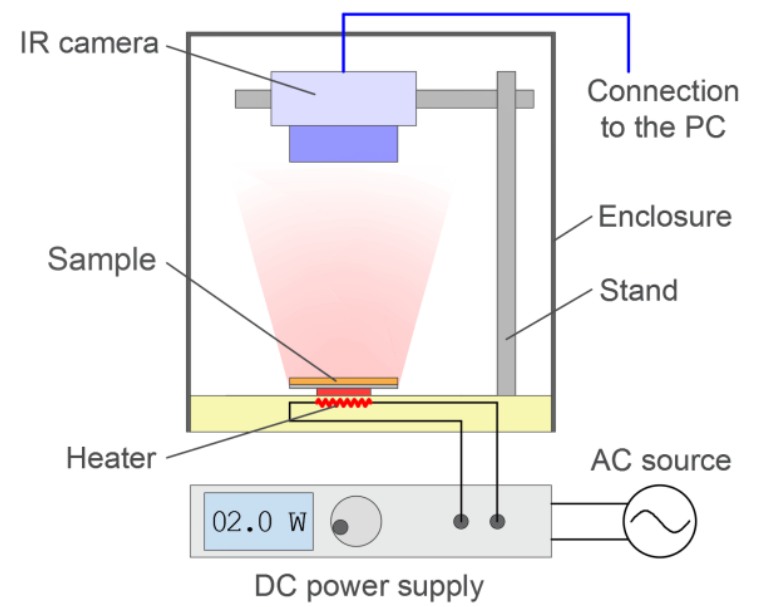

Figure 1 Schematic diagram of the thermal test setup

\subsection{RESULTS AND DISCUSSION}

\subsection{Condition of the rGO Layer on $\mathrm{Si}$}

The structure of $\mathrm{rGO} / \mathrm{Si}$ is feasible for non-destructive optical characterization to study the film condition. Figure 2 (a) shows the Raman spectra and thickness of the rGO (1) - (4) film on the Si substrate. There were 2 prominent intensity peaks identified, where I(D) at $1372 \mathrm{~cm}^{-1}$ corresponds to the disorder in $\mathrm{sp}^{2}$ carbon while $/(\mathrm{G})$ at $\sim 1600 \mathrm{~cm}^{-1}$ corresponds to the first-order phonons scattering in the graphitic materials [17]. The full width at half-maximum of I(D) and $/(G)$ was $153 \mathrm{~cm}^{-1}$ and $70 \mathrm{~cm}^{-1}$, respectively as obtained from Lorentzian fitting of the individual spectra in the plot. The presence of both peaks confirms the presence of continuous coverage of rGO sheets on the Si substrate. The ratio of I(D)/I(G) can be used as an indicator to evaluate the amount of defect in graphene lattice. Since the reduction process took place in similar chamber conditions, I(D)/I(G) of the rGO (1) - (4) films were almost similar in an average of 0.987 . This value represents a high degree of defect on graphene lattice and will be discussed later on.

Figure 2 (b) shows the measured thickness of rGO film for different times of GO drop-cast deposition. A high degree of accuracy in the thickness of $\mathrm{rGO}$ film can be obtained by applying the Tauc-Lorentz fitting model on ellipsometry data as described in ref. [18]. In this work, we found increasing the amount of GO drop-cast does not linearly increase the final $r G O$ thickness. Single drop-cast results in an average thickness of approximately $227 \mathrm{~nm}$. During the first drop-cast of GO droplet, GO sheets were dispersed on the whole circular area of Si substrate. Slow-drying of GO droplet helps in the settlement of GO sheets almost as a continuous film. Surface tension between hydrophobic $\mathrm{sp}^{2}$ carbon (un-oxidized basal plane) and hydrophobic $\mathrm{Si}$ results in the formation of thickness non-uniformity. Single drop-cast GO after subjected to the thermal reduction results in $\mathrm{rGO}$ with thickness standard error (SE) of $\pm 23 \mathrm{~nm}$.

Further drop-cast 2 - 4 times result in the thickness of GO film approaching $300 \mathrm{~nm}$. We did not observe a linear increase in $\mathrm{rGO}$ thickness for every increase in GO drop-cast. Since GO sheets already covered the hydrophobic Si surface, 2 times drop-cast establish a more uniform thickness of GO film, supported by the lowered SE to only $\pm 1 \mathrm{~nm}$. However, 3 and 4 times drop-cast did not significantly increase the thickness due to the movement of GO sheets to the perimeter area of the circle. This is one of the disadvantages of forming $\mathrm{GO}$ film by dropcasting method; it is associated with the 'coffee ring effect'. Therefore, the thickness of rGO at the center (area where the ellipsometry measurements were carried out) did not show a significant increment.
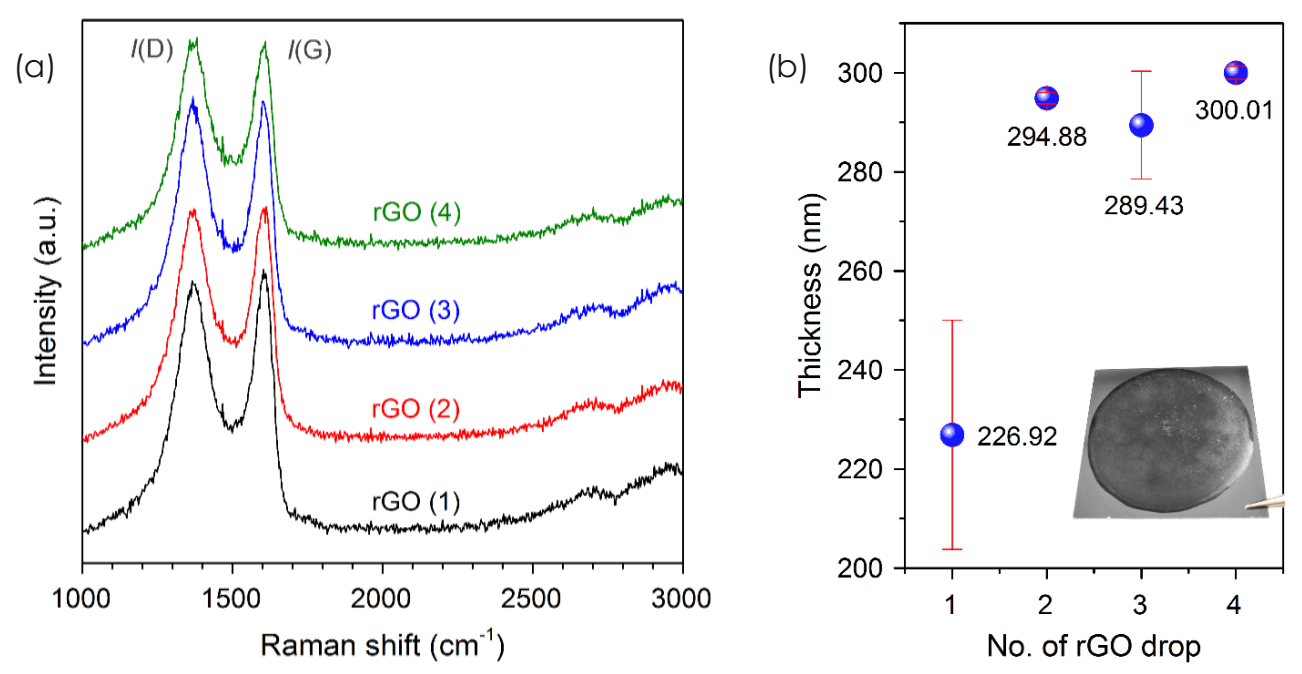

Figure 2 (a) Raman spectra, (b) thickness of rGO (1) - (4) film on Si substrate 
Figure 3 (a) - (d) show the surface morphology of rGO film for a varied amount of GO drop-cast onto Si substrate. During slow-drying of GO droplet on the hotplate, evaporation of water enforces GO sheets to settle down and stick to the hydrophobic Si surface. When the film undergoes heat treatment, GO sheets at the outer layer have more tendency to be reduced into rGO compared to the embedded sheets. Inner GO sheets still serve the purpose as a stickiness agent to the Si substrate. We can observe from the FESEM images the outer GO layer shrank and some of them crumpled as a ball-like structure after the thermal reduction process. Meanwhile, inner GO sheets that survived after thermal reduction appeared as a cloudy-like layer embedded under the rGO outer layer. This also points out the fact that our reduction process exactly can provide a hybrid layer of GO-rGO as the consequence of incomplete de-oxygenation.

The presence of distinguishable inner GO layer and outer rGO layer for the GO film subjected to the thermal reduction at $700{ }^{\circ} \mathrm{C}$ in $\mathrm{H}_{2}$ environment was discussed in our previous work in ref. [18], where it exhibited tunable optoelectronic properties according to the thickness of the hybrid GO-rGO film. In this work, previous Raman spectra suggest a complementary explanation to the FESEM images, where the survived embedded GO sheets (cloudylike layer) give the most optical response about the crystal condition of the film. The I(D)/I(G) of the rGO (1) - (4) on average of 0.987 is actually coming from the embedded GO. The optical response from the highly reduced $\mathrm{rGO}$ at the outer surface (expected I(D)/I(G) > 1) was overshadowed by GO, perhaps

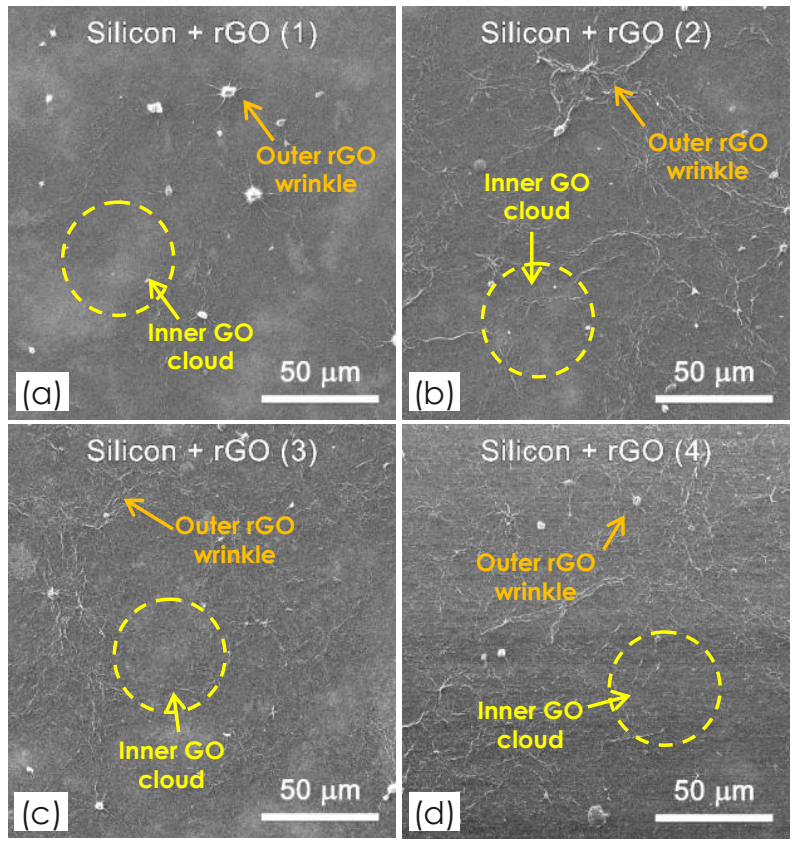

Figure 3 (a) - (d) FESEM images of rGO (1) - (4) film on Si substrate, respectively due to the difference in their population ratio. Electrically insulating $\mathrm{GO}$ with mediocre thermal conductivity at the inner surface combined with restored high thermal conductivity rGO at the outer surface is the potential solution to the thermal management, where they avoid inducing shortcircuit complication in the device.

\subsection{Thermal Performance of rGO Layer on Si}

The thermal characteristic of the bare Si sample (ref. sample) without rGO TIM and heat spreader is shown in Figure 4 (a). In the figure, heater (base) temperature is the temperature reading at the controller of the heater. The heating rate of $\mathrm{Pt}$ heater without the sample was pre-determined to be 45.03 -C/W. Meanwhile, average hotspot area and Si area temperature is the averaged temperature reading from IR camera for $1 \times 1 \mathrm{~cm}^{2}$ heater plate and $3 \times 3$ $\mathrm{cm}^{2}$ Si substrate. This heating and monitoring technique is the improved method from our previous report [19]. A linear fitting has taken from heating power, $Q>2 \mathrm{~W}$ to extract the rate of temperature rise. Within this region, a large amount of heat transferred from the heater to the Si substrate compared to the small and consistent heat loss to the surrounding. The heat map in Figure 4 (b) shows the steady-state heat distribution at the maximum $Q$ of the sample.

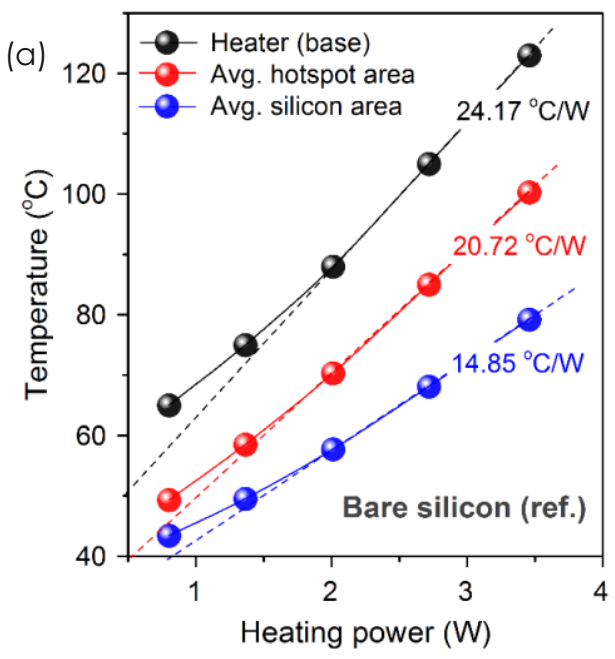

(b)

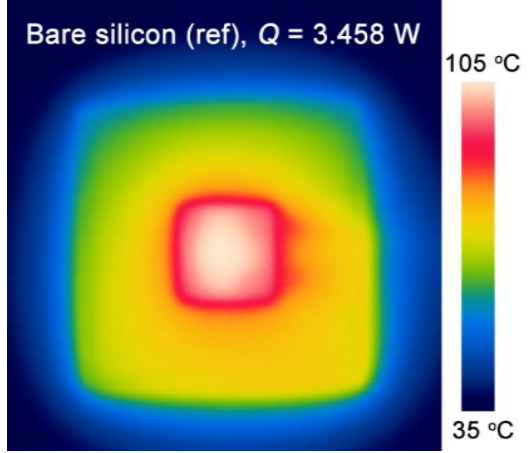

Figure 4 (a) Thermal characteristic, (b) heat map of Si without heat spreader 
Figure 5 (a) - (d) compares the rate of temperature rise of the Si substrate with rGO (1) - (4) film. The heating rate of the heater (base) as read by the controller is consistent around $24{ }^{\circ} \mathrm{C} / \mathrm{W}$ for every measurement, with or without the rGO film. This is well anticipated since our linear fitting was taken in high power region of $Q>2 \mathrm{~W}$ and the heater correspond straightforwardly to the $Q$. We can observe a modest cooling effect of the heater at low power region $Q<$ $2 \mathrm{~W}$ where the presence of thicker rGO film facilitated heat transfer into the Si substrate rather than loss to the heater surrounding. This argument is supported by judging the overall hotspot heating rate of the sample with rGO film, where they are around $22^{\circ} \mathrm{C} / \mathrm{W}$ higher compared to the bare $\mathrm{Si}$ sample $20.72^{\circ} \mathrm{C} / \mathrm{W}$.
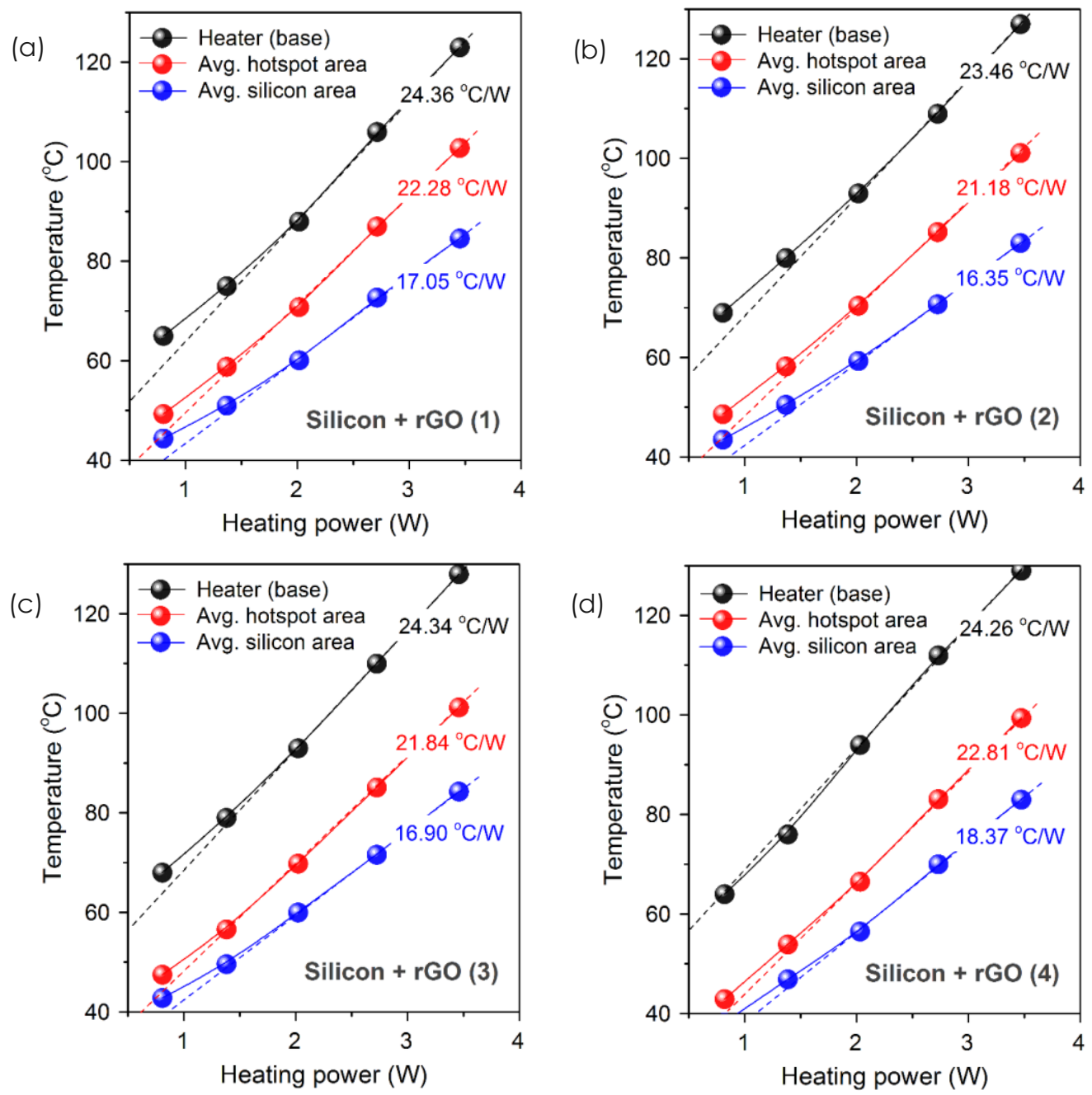

Figure 5 (a) - (d) Thermal characteristic of Si with rGO (1) - (4) film, respectively
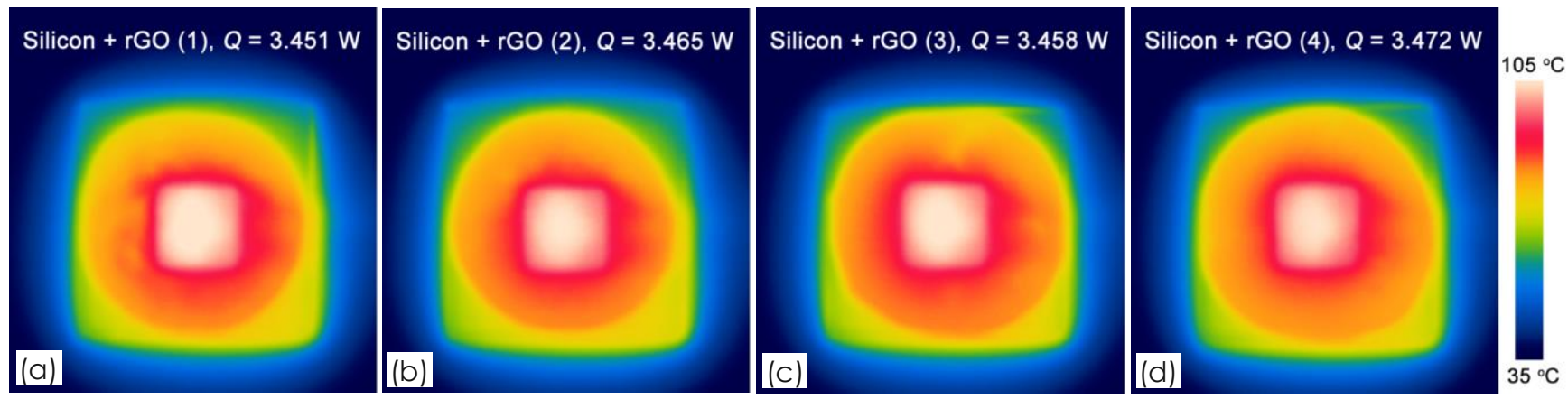

Figure 6 (a) - (d) Heat map of Si with rGO (1) - (4) film, respectively 
Higher hotspot temperature, in this case, indicates a more efficient heat transfer from the heater to the Si substrate that contributed by the rGO TIM. During the operation, a major portion of heat vertically transferred by rGO TIM into the Si substrate thus appeared as a $1 \times 1 \mathrm{~cm}^{2}$ hotspot. Another portion of heat laterally spread and transferred by rGO heat spreader, thus contributed to the overall temperature rise in $\mathrm{Si}$ substrate. The plot of the average temperature on the $\mathrm{Si}$ area in Figure 5 shows the heating rate of $3 \times 3 \mathrm{~cm}^{2}$ si substrate with a combined contribution from the vertical and lateral spread by rGO. The heating rate of Si improved from $14.85^{\circ} \mathrm{C} / \mathrm{W}$ (bare Si) to around $17^{\circ} \mathrm{C} / \mathrm{W}$ with $\mathrm{rGO}(1)$ - (3) layer, and up to $18.37 \circ \mathrm{C} / \mathrm{W}$ for the Si with rGO (4) layer.

Figure 6 (a) - (d) provides the heat map comparison of Si with rGO (1) - (4) film. We can observe the temperature gradient in each sample from the center of the hotspot spread to the edges by the circular rGO films. Therefore, the average heating rates of $3 \times 3 \mathrm{~cm}^{2}$ Si were improved and the heat was distributed more uniformly across the area. In this experiment, we need to remark that the high heating rate of Si substrate signifying the positive outcome and is directly related to the performance of the rGO layer as a TIM and heat spreader. The cooling of the Si substrate is will be delivered by the heatsink component, which is omitted in this experimental design to circumvent the heat loss. Readers may find similar research works employed IR camera for monitoring and imaging refer to the increase in substrate temperature as a negative outcome $[20,21]$, which seems contrary to our work. While it is actually not because they investigated the function of graphene as a heat spreader + heat dissipation (heatsink), rather than function as TIM + heat spreader that is highlighted in this report. In terms of choosing the optimum sample between rGO (1) - (4), we found the thickness of the rGO does not significantly alter the heat spreading performance. We suggest the thickness around $300 \mathrm{~nm}$ suitable considering the highest heating rate of Si with rGO (4) film in addition to the uniform heat map distribution.

\subsection{CONCLUSION}

In this work, a simple formation of the rGO layer on $\mathrm{Si}$ by drop-cast followed by thermal reduction was evaluated its performance as a TIM and heat spreader layer. By this approach, high stickiness to the Si substrate while at the same time providing high thermal conductivity for heat distribution is realized. Electrically insulating oxygen-functionalized GO that survived thermal reduction is important to provide stickiness, avoiding thermally conductive rGO peeled-off from the Si during heat loading and unloading. This eventually determines the durability of the device during the operation. Improved heat transfer and spreading in Si substrate by the optimum around $300 \mathrm{~nm}$-thick rGO film was justified from the heating profile and heat map. In this work, Si served as a dummy just to demonstrate the capability of rGO as a TIM and heat spreader. Encouraging data from this work paves a way for an actual demonstration of electrically insulating GO-rGO as a TIM and heat spreader in lowering hotspot temperature in power device e.g. Ill-nitrides power transistor.

On another important remark, our custom builds thermal test setup is now verified as a capable system in evaluating the thermal performance of TIM and heat spreader materials. Both qualitative and quantitative data provided by the system enable deeper analysis of the sample and they are also applicable to the other materials of interest. Findings in this work are helpful for heat management strategy and testing methodology in high operating temperature devices.

\section{Acknowledgment}

This project is internally funded by MIMOS Berhad.

\section{References}

[1] Mat Hussin, M. R., Ramli, M. M., Wan Sabli, S. K., Md Nasir, I., Syono, M. I., Wong, H. Y., and Zaman, M. 2017. Fabrication and Characterization of Graphene-on-Silicon Schottky Diode for Advanced Power Electronic Design. Sains Malaysiana. 46(7): $1147-1154$.

[2] Mohd Saman, R., Wan Sabli, S. K., Mat Hussin, M. R. Othman, M. H., Mohammad Haniff, M. A. S., and Syono, M. I. 2019. High Voltage Graphene Nanowall Trench MOS Barrier Schottky Diode Characterization for High Temperature Applications. Appl. Sci. 9(8): 1587.

[3] Lv, L., Dai, W., Li, A., and Lin, C. T. 2018. Graphene-Based Thermal Interface Materials: An Application-Oriented Perspective on Architecture Design. Polymers 10(11): 1201.

[4] Ghosh, S., Calizo, I., Teweldebrhan, D., Pokatilov, E. P. Nika D. L., Balandin, A. A., Bao, W., Miao, F., and Lau, C. N. 2008. Extremely High Thermal Conductivity of Graphene: Prospects for Thermal Management Applications in Nanoelectronic Circuits. Appl. Phys. Lett. 92: 151911.

[5] Zeng, Y., Li, T., Yao, Y., Li, T., Hu, L., and Marconnet, A. 2019. Thermally Conductive Reduced Graphene Oxide Thin Films for Extreme Temperature Sensors. Adv. Funct. Mater. 29 (27): 1901388.

[6] Yan, Z., Liu, G., Khan, J. M., and Balandin, A. A. 2012 Graphene Quilts for Thermal Management of High-Power GaN Transistors. Nat. Commun. 3: 827.

[7] Subrina, S., Kotchetkov, D., and Balandin, A. A. 2009. Heat Removal in Silicon-on-Insulator Integrated Circuits with Graphene Lateral Heat Spreaders. IEEE Electron Device Lett. 30(12): 1281-1283.

[8] Hanifah, M. F. R., Jaafar, J., Aziz, M., Ismail, A. F., Rahman, M. A., and Othman, M. H. D. 2015. Synthesis of Graphene Oxide Nanosheets via Modified Hummers' Method and its Physicochemical Properties. J. Teknol. 74(1): 189-192.

[9] Cote, L. J., Kim, J., Tung, V. C., Luo, J., Kim, F., and Huang, J. 2011. Graphene Oxide as Surfactant Sheets. Pure Appl. Chem. 83(1): 95-110.

[10] Abdullah, M. F. and Hashim, A. M. 2019. Review and Assessment of Photovoltaic Performance of Graphene/Si Heterojunction Solar Cells. J. Mater. Sci. 54(2): 911-948. 
[11] Abdullah, M. F. and Hashim, A. M. 2019. Improved Coverage of rGO Film on Textured Si Inverted Micro Pyramids for Enhancing Photovoltaic of $\mathrm{rGO} / \mathrm{Si}$ Heterojunction Solar Cell. Mater. Sci. Semicond. Process. 96: 137-144.

[12] Jin, S., Gao, Q., Zeng, X., Zhang, R., Liu, K., Shao, X., and Jin, M. 2015. Effects of Reduction Methods on the Structure and Thermal Conductivity of Free-Standing Reduced Graphene Oxide Films. Diam. Relat. Mater. 58: 54-61.

[13] Jang, W., Bao, W., Jing, L., Lau, C. N., and Dames, C. 2013. Thermal Conductivity of Suspended Few-Layer Graphene by a Modified T-Bridge Method. Appl. Phys. Lett. 103(13): 133102.

[14] Zhang, X., Sun, D., Li, Y., Lee, G. H., Cui, X., Chenet, D., You, Y., Heinz, T. F., and Hone, J. C. 2015. Measurement of Lateral and Interfacial Thermal Conductivity of Single- and Bilayer $\mathrm{MOS}_{2}$ and $\mathrm{MoSe}_{2}$ Using Refined Optothermal Raman Technique. ACS Appl. Mater. Interfaces 7(46): 25923-25929.

[15] Marcano, D. C., Kosynkin, D. V., Berlin, J. M., Sinitskii, A. Sun, Z., Slesarev, A. S., Alemany, L. B., Lu, W., and Tour, J. M. 2010. Improved Synthesis of Graphene Oxide. ACS Nano 4(8): 4806-4814.

[16] Abdullah, M. F., Abd Rahman, S. F. and Hashim, A. M. 2019. Investigation on Transition Diode Properties of rGO-
GO/n-Si Heterojunction. Phys. Status Solidi A. 216(14): 1900064.

[17] Ferrari, A. C., Meyer, J. C., Scardaci, V., Casiraghi, C., Lazzeri, M., Mauri, F., Piscanec, S., Jiang, D., Novoselov, K. S., Roth, S., and Geim, A. K. 2006. Raman Spectrum of Graphene and Graphene Layers. Phys. Rev. Lett. 97(18): 187401.

[18] Abdullah, M. F., Soriadi, N., Md Yakin, F. S., Mohamad Badaruddin, S. A., and Syono, M. I. 2020. Tuning the Optoelectronic Properties of the rGO-AuNPs Hybrid Film by Pre-Decoration and AuNPs-Assisted Thermal Reduction. Mater. Sci. Semicond. Process. 112: 105017.

[19] Mat Hussin, M. R., Mohamad Badaruddin, S. A., Mohd Nor, N. M. R., and Hamzah, M. H. A. 2019. Ultrasonic Atomization of Graphene Derivatives for Heat Spreader Thin Film Deposition on Silicon Substrate. Materials Today: Proceedings 7(2): 763-769.

[20] Li, X., Fang, M., Wang, W., Guo, S., Liu, W., Liu, H., and Wang, X. 2016. Graphene Heat Dissipation Film for Thermal Management of Hot Spot in Electronic Device. J. Mater Sci.: Mater. Electron. 27: 7715-7721.

[21] Deng, D. and Xiong, X. 2018. Free-Standing Paper-Like Heat Spreading Films Based on Graphene Oxide-Aromatic Molecule Composites. J. Mater. Sci.: Mater. Electron. 29: 3050-3055. 